\title{
Genetic evolution of low pathogenecity H9N2 Avian influenza viruses in Tunisia: acquisition of new mutations
}

\author{
Wafa Tombari ${ }^{1}$, Jihene Nsiri ${ }^{1}$, Imen Larbi ${ }^{1}$, Jean Luc Guerin ${ }^{2}$ and Abdeljelil Ghram ${ }^{*}$
}

\begin{abstract}
Background: Since the end of 2009, H9N2 has emerged in Tunisia causing several epidemics in poultry industry resulting in major economic losses. To monitor variations of Influenza viruses during the outbreaks, Tunisian H9N2 virus isolates were identified and genetically characterized.
\end{abstract}

Methods: The genomic RNA segments of Tunisian H9N2 strains were subjected to RT-PCR amplifications followed by sequencing analysis.

Results: Phylogenetic analysis demonstrated that A/CK/TUN/12/10 and A/Migratory Bird/TUN/51/10 viruses represent multiple reassortant lineages, with genes coming from Middle East strains, and share the common ancestor Qa/HK/G1/97 isolate which has contributed internal genes of H5N1 virus circulating in Asia. Some of the internal genes seemed to have undergone broad reassortments with other influenza subtypes. Deduced amino acid sequences of the hemagglutinin (HA) gene showed the presence of additional glycosylation site and Leu at position 234 indicating to binding preference to $\alpha(2,6)$ sialic acid receptors, indicating their potential to directly infect humans. The Hemagglutinin cleavage site motif sequence is ${ }^{333}$ PARSSR $^{*}$ GLF $^{341}$ which indicates the low pathogenicity nature of the Tunisian H9N2 strains and the potential to acquire the basic amino acids required for the highly pathogenic strains. Their neuraminidase protein (NA) carried substitutions in the hemadsorption (HB) site, similar to those of other avian H9N2 viruses from Asia, Middle Eastern and human pandemic H2N2 and H3N2 that bind to $\alpha-2,6$-linked receptors. Two avian virus-like aa at positions 661 (A) and $702(\mathrm{~K})$, similar to H5N1 strains, were identified in the polymerase (PB2) protein. Likewise, matrix (M) protein carried some substitutions which are linked with increasing replication in mammals. In addition, H9N2 strain recently circulating carried new polymorphism, "GSEV" PDZ ligand (PL) C-terminal motif in its non structural (NS) protein.

Two new aa substitutions (I) and $(V)$, that haven't been previously reported, were identified in the polymerase and matrix proteins, respectively. Nucleoprotein and non-structural protein carried some substitutions similar to H5N1 strains.

Conclusion: Considering these new mutations, the molecular basis of tropism, host responses and enhanced virulence will be defined and studied. Otherwise, Continuous monitoring of viral genetic changes throughout the year is warranted to monitor variations of Influenza viruses in the field.

\section{Background}

Avian Influenza virus (AIV) is a member of the family Orthomyxoviridae; containing negative sense single stranded RNA [1]. Based on their pathogenecity, Two types of AIV have been described, namely a highly pathogenic type (HPAIV) that causes severe disease with

\footnotetext{
* Correspondence: abdeljelil.ghram@pasteur.rns.tn

${ }^{1}$ Veterinary Microbiology laboratory, Pasteur Institute of Tunis, 1002 TunisBelvédère, Tunisia Full list of author information is available at the end of the article
}

high mortality, and low pathogenic type (LPAIV) inducing asymptomatic or mild infection [2]. AIV subtypes, namely $\mathrm{H} 5, \mathrm{H} 7$ and $\mathrm{H} 9$, currently endemic in poultry in some regions of the world, have been shown to be capable of infecting humans $[3,4]$.

By 1997, H9N2 viruses have been isolated in multiple avian species including chickens, ducks, turkeys, quail, geese and pigeons, throughout Asia, the Middle East, Europe and Africa and for the first time from humans in Hong Kong and China, in 1999 [5-7]. They could
C Biomed Central 
emerge as human pathogens through reassortment in intermediate hosts, such as pigs [6] and in avian species, or through direct adaptation in human host [8]. These viruses produce significant disease problems in poultry resulting in great economic losses due to reduced egg production or high mortality with co-infection with other opportunistic pathogens such as infectious bronchitis viruses [9], Staphylococcus aureus, Avibacterium paragallinarum, Escherichia coli, or immune suppression [10].

Two distinct lineages of H9N2 influenza viruses have been defined, the North American lineage and the Eurasian lineages which consists of at least three sublineages represented by their prototype strains: A/quail/Hong Kong/G1/97 (G1-like), A/duck/HongKong/Y280/9 (Y280-like), A/Chicken/Beijing/1/94 (BJ94-like), and A/ chicken/Korea/38349-P96323/96 (Korean-like) [11,12]. The A/quail/Hong Kong/G1/97 is thought to be the donor of 6 internal genes to the poultry and the human H5N1 viruses isolated in 1997 [8].

In addition, some of these currently circulating H9N2 strains have acquired human-like receptor specificity ( $\alpha 2,6$ sialic acids) [13] and there is concern about the potential risk for these viruses to cross the species barriers and affect human health as the consequences of genetic reassortments between mammalian and avian influenza virus.

Since the end of 2009, H9N2 has emerged in Tunisia causing several epidemics in poultry industry resulting in major economic losses. It should be noted that
Tunisia was reportedly free from Avian Influenza infection [14].

In the present study, we report the isolation of two Tunisian H9N2 influenza viruses that were identified, and their genome sequences were analyzed. Phylogenetic analysis characterization was performed in comparison to H9N2 sequences available in the Genbank database.

\section{Materials and methods}

Fecal and tissue samples were collected from affected commercial poultry and from migratory bird during the initial outbreak. H9N2 avian influenza viruses were isolated and identified using classical laboratory methods [15]. The isolates were propagated in specific-pathogen free (SPF) chicken embryonated eggs via the allontoic route, and the eggs were incubated for $72-96 \mathrm{~h}$ at $37^{\circ} \mathrm{C}$. The collected allontoic fluids were subjected to hemagglutination and hemagglutination inhibition tests using H9 monospecific polyclonal antisera obtained from F.A. $O$. The genomic RNA segments of viruses were extracted using viral Trizol LS reagent (Invitrogen, Carlsbad, CA) according to the manufacturer's instruction. The first-strand cDNA was synthesized using SuperScript ${ }^{\mathrm{TM}}$ III Reverse transcriptase (Invitrogen, Carlsbad, CA) and appropriate upstream primers. cDNA was amplified by PCR using described IA specific primers listed in Table 1. $5 \mu \mathrm{l}$ of cDNA was added to the PCR reaction mixture $(25 \mu \mathrm{l})$ containing $2,5 \mu \mathrm{l}$ of $10 \times$ PCR buffer, 2, $5 \mu \mathrm{l}$ of 2, $5 \mathrm{mM}$ dNTPs, $0,5 \mu \mathrm{l}$ Taq

Table 1 Primer sequences as used in the RT-PCR in our study

\begin{tabular}{|c|c|c|c|c|}
\hline Name & Sequence $\left(5^{\prime}-3^{\prime}\right)^{a}$ & Position & $\begin{array}{l}\text { Expected products } \\
\text { size }(\mathrm{pb})\end{array}$ & Reference \\
\hline AMF & СTTCTAACCGAGGTCGAAAC & $7-26$ & 244 & 15 \\
\hline AMR & AGGGCATTTTGGACAAAKCGTCTA & $259-238$ & & \\
\hline MF & CTCATGGAATGGCTAAAGACA & $149-169$ & 700 & 16 \\
\hline MR & CGATCAADAATCCACAATATC & $847-827$ & & \\
\hline H9-1 & CTYCACACAGARCACAATGG & $184-203$ & 488 & 15 \\
\hline H9-2 & GTCACACTTGTTGTTGTRTC & $672-652$ & & \\
\hline $\mathrm{H} 9 \mathrm{~F}$ & GAATCCAGATCTTTCCAGAC & $426-445$ & 384 & 17 \\
\hline H9R & CCATACCATGGGGCAATTAG & $808-789$ & & \\
\hline NPF & CAGRTACTGGGCHATAAGRAC & $1200-1220$ & 326 & 18 \\
\hline NPR & GCA TTGTCTCCGAAGAAATAAG & $1529-1510$ & & \\
\hline HAF1 & GAATTGATTATTATTGGTCAGTA & $710-732$ & 550 & 19 \\
\hline HAR1 & TCATCAATCT-TATTGTTGATCAT & $1272-1249$ & & \\
\hline NAF & CTTGTTGGCGACACACCAAGRAA & $961-983$ & 410 & 19 \\
\hline NAR & GAGCCTGTTCCAT-AGGTACCTGA & $1370-1348$ & & \\
\hline PB2F & TATTCAT-CRTCAATGATGTGGGA & $1591-1613$ & 540 & 19 \\
\hline PB2R & GATGCTYAATGCTGGTCCATATC & $2130-2108$ & & \\
\hline NSF & AGCAAAAGCAGGGTGACAAA & $1-20$ & 890 & 20 \\
\hline NSR & AGTAGAAACAAGGGTGTTTT & $890-871$ & & \\
\hline
\end{tabular}

\footnotetext{
${ }^{a}$ Codes for mixed bases positions: $\mathrm{D}=\mathrm{G} / \mathrm{A} / \mathrm{T}, \mathrm{H}=\mathrm{A} / \mathrm{C} / \mathrm{T}, \mathrm{K}=\mathrm{G} / \mathrm{T}, \mathrm{R}=\mathrm{A} / \mathrm{G}, \mathrm{Y}=\mathrm{C} / \mathrm{T}$.
} 
DNA polymerase (5 units/ $\mu$ l, Invitrogen), $1 \mu \mathrm{l}$ of each primer (10 pmol each), $2 \mu \mathrm{l}$ of $5 \mathrm{Mm} \mathrm{Mgcl}_{2}$ (Invitrogen, Carlsbad, CA) and 17, $5 \mu \mathrm{l}$ of $\mathrm{H}_{2} \mathrm{O}$ RNase free (BioBasic, Carlsbad, CA). The PCR program was $94^{\circ} \mathrm{C}$ for $2 \mathrm{~min}$, 35 cycles of $94^{\circ} \mathrm{C}$ for $45 \mathrm{~s}, 50^{\circ} \mathrm{C}$ for $45 \mathrm{~s}$ [15-18] $\left(58^{\circ} \mathrm{C}\right.$ for HA1, NA, PB2, and NS) [19,20], $72^{\circ} \mathrm{C}$ for $1 \mathrm{~min}$ followed by $72^{\circ} \mathrm{C}$ for $10 \mathrm{~min}$. PCR products were purified with gel DNA purification kit (GenClean ${ }^{\circledR}$ II kit, North America, MP).

ABI Big Dye Terminator version 1.1 sequencing Kit run on 3730 XL DNA Analyzed (ABI prism 377, DNA sequencer, Applied Biosystem Inc., CA, USA) sequencer was used for sequencing PCR products.

The Bioedit program 5.0.6 software and ClustalW alignement algorithm (version 1.83) were initially used to compare and align nucleotide sequences. Phylogenetic trees were constructed using MEGA5.01 program version 3.65 with neighbor-joining method. The robustness of the groupings in the neighbor-joining analysis was assessed with 1000 bootstrap resamplings. The Blast software and Bioedit programs were used to determine the sequence similarity of the Tunisian strains

Nucleotide sequence accession numbers: the nucleotide sequences obtained in this study were deposited in GenBank data library under accession numbers: JF323006 to JF323016.

Number of amino acid residues: amino acid residues were numbered according to the HA sequences of $\mathrm{Qu} /$ HK/G1/97 (H9) with GenBank accession number AF156378.

\section{Results}

Phylogenetic analyses of surface genes of H9N2 viruses

To determine evolutionary relationships between Tunisian H9N2 isolates and those selected from the Genbank (Table 2), phylogenetic analyses were carried out for 6 viral gene segments (i.e., the genes for hemagglutinin (HA), neuraminidase (NA), polymerase (PB2), nucleoprotein (NP), matrix (M) and non structural (NS)) (Figure 1).

Phylogenetic analyses based on the HA (Figure 1a) and NA (Figure 1b) genes (nucleotides 125 to 1272 and 961 to 1370, respectively), revealed that current Tunisian (H9N2) viruses are closely related to each other and shared closed relationship with the Middle Eastern strains, especially A/Av/SA/91013406/06, A/Ck/Em/ R666/02, A/Ck/Du/338/01 and Ck/Pak/UL01/08. Percentage similarity scores, calculated from pairwaise alignments, supported the phylogenetic results and revealed a similarity score of more than 96\% (Table 3). Tree analyses showed that Middle Eastern strains are grouped in G1 lineage and shared a common ancestor with A/Quail/Hong Kong/G1/1997 isolates.

\section{Phylogenetic analyses of internal genes}

Four internal genes (PB2, NP, M and NS) of Tunisian H9N2 strains showed more than 96\% nucleotide identity with those of the Middle Eastern strains isolated from 2001 and 2008 (Table 3).

The phylogenetic studies of the PB2 genes were analysed using the 540- base-long nucleotide sequence

Table 2 Abbreviations used and GenBank accession numbers for H9N2 Avian Influenza virus isolates included in phylogenetic analysis

\begin{tabular}{|c|c|c|c|c|c|c|c|}
\hline \multirow[t]{2}{*}{ References strains } & \multirow[t]{2}{*}{ Abbreviations } & \multicolumn{6}{|c|}{ Accession number } \\
\hline & & $\mathrm{HA}$ & NA & PB2 & NP & $\mathbf{M}$ & NS \\
\hline Chicken/Tunisia/12/10 & Ck/TUN/12/10 & JF323006 & JF323008 & JF323010 & JF323012 & JF323014 & JF323016 \\
\hline Migratory bird/Tunisia/51/10 ${ }^{a}$ & MB/TUN/51/10 & $J F 323007$ & $J F 323007$ & $J F 323007$ & $J F 323007$ & $J F 323007$ & $J F 323007$ \\
\hline Quail/Hong Kong/G1/97 & QuHKG197 & AF156378 & AF156336 & AF156435 & AF156407 & AF156463 & $-{ }^{b}$ \\
\hline Duck/Hong Kong/Y280/97 & DKHKY280097 & AF156376 & AF156394 & AF156433 & - & AF156461 & AF156475 \\
\hline Chicken/Hong Kong/G9/97 & CKHKG997 & AF156373 & AF156391 & AF156430 & AF156402 & AF156458 & AF156472 \\
\hline Chicken/Emirates/R66/02 & CKEmR6602 & CY076723 & CY076725 & CY076720 & CY076724 & CY076726 & CY076727 \\
\hline Chicken/Dubai/338/01 & CKDu33801 & EF063520 & EF063520 & EF063555 & EF063527 & EF063506 & EF063541 \\
\hline Chicken/Dubai/339/01 & CKDu33901 & EF063514 & EF063521 & EF063556 & EF063528 & EF063507 & EF063542 \\
\hline Chicken/Dubai/383/02 & CKDu38302 & EF063515 & EF063522 & EF063557 & EF063529 & EF063508 & EF063543 \\
\hline Chicken/Dubai/463/03 & CKDu46303 & EF063516 & EF063523 & EF063558 & EF063530 & EF063509 & EF063544 \\
\hline Chicken/Pakistan/UDL-01/05 & CKPaUDL0105 & CY038458 & CY038412 & CY038407 & CY038411 & CY038461 & CY038462 \\
\hline Chicken/Pakistan/UDL-01/08 & CKPaUDL0108 & CY038410 & CY038460 & CY038455 & CY038459 & CY038413 & CY038462 \\
\hline Avian/Saudi Arabia/910135/06 & AvSA91013506 & GU050287 & GU050297 & GU050294 & GU050287 & GU050287 & GU050287 \\
\hline Avian/Saudi Arabia/910136/06 & AvSA91013606 & GU050295 & GU050289 & GU050302 & GU050298 & GU050296 & GU050287 \\
\hline Chicken/Israel/386/07 & Ckls38607 & - & FJ464619 & - & FJ464636 & FJ464602 & FJ464653 \\
\hline Chicken/Israel/292/08 & Ckls29208 & FJ464617 & FJ464616 & - & - & FJ464599 & FJ464650 \\
\hline
\end{tabular}

${ }^{a}$ Viruses whose HA, NA, PB2, NP, M and NS genes were sequenced in the present study; N.D, not done; ${ }^{b}$, - No sequence data available. 
(a) HA

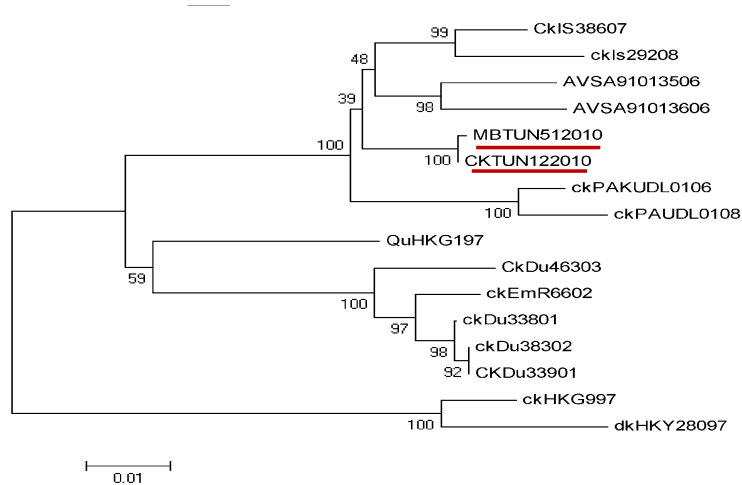

(c) PB2

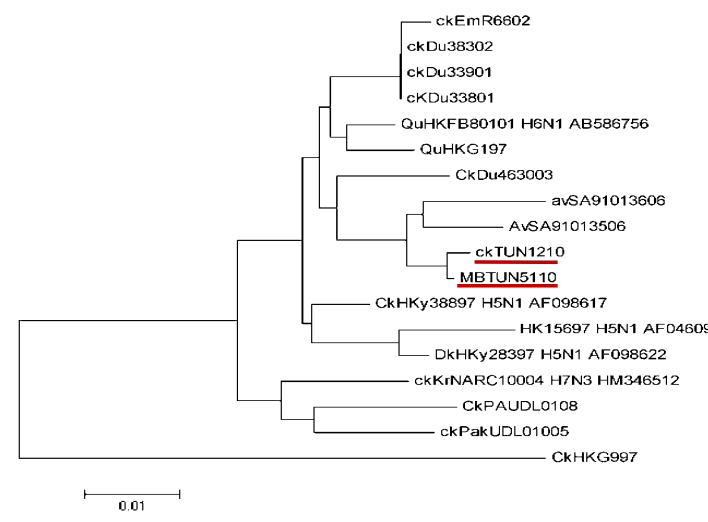

(c) $\mathbf{M}$

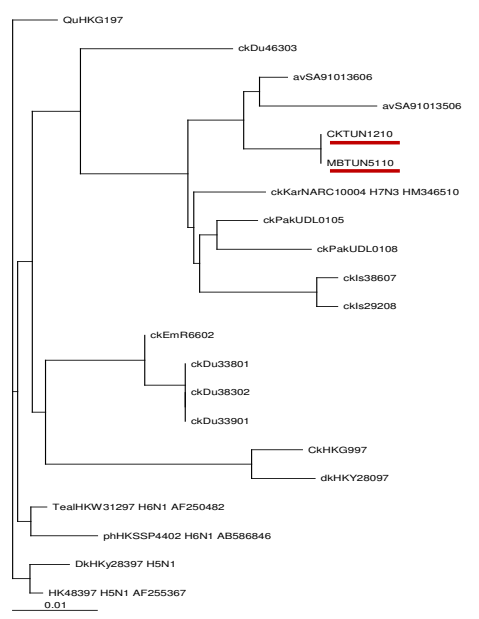

(b) NA

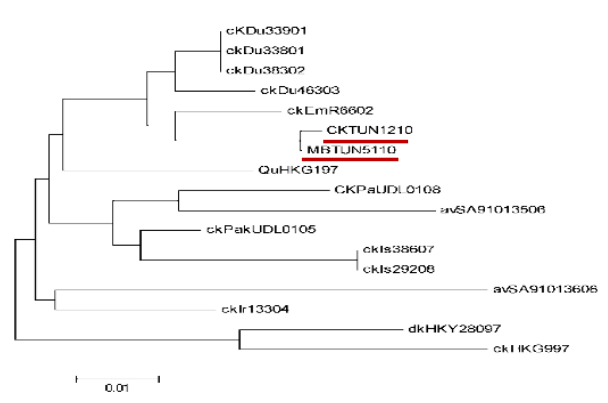

(d) NP

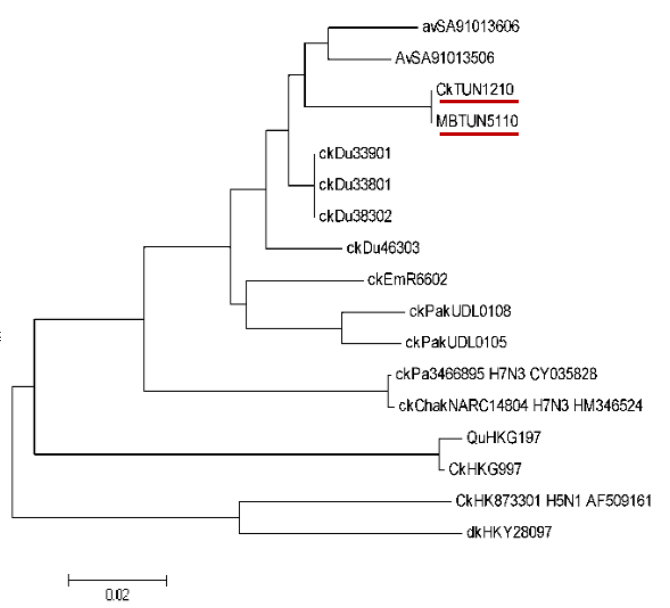

(d) NS

Figure 1 Phylogenetic trees of the HA (a) (1072 bp from 184 to 1272), NA (b) (410 bp from 961 to 1370 ), PB2 (c) (540 bp from 1591 to 2130 ), NP (d) (326 bp from 1200 to 1529), M (e) (840 bp from 7 to 847) and NS (f) (890 bp from 1 to 890) genes of Tunisian

Influenza A viruses. The trees were generated by the distance-based neighbor-joining method using MEGA, version 5.0 program. The reliability of the trees was assessed by bootstrap analysis with 1, 000 replications; only bootstarp values of $>90 \%$ are shown. The length of the horizontal lines is proportional to the minimum number of nucleotide differences required to join nodes. The vertical lines are for spacing branches and labels. Abbreviations used in virus designation are as follows: Av, avian; Ck, chicken; Dk, duck; gs, goose; Qu, quail; Pa, paraket. The underlined strains are avian H9N2 Influenza viruses' isolates and sequenced in the present study. 
Table 3 Percentage similarity between the gene segments of Tunisian isolates with those of reference viruses

\begin{tabular}{|c|c|c|c|c|c|c|c|c|c|}
\hline \multicolumn{10}{|c|}{ Identity (\%) ${ }^{a}$} \\
\hline $\begin{array}{l}\text { Tunisian } \\
\text { isolates }\end{array}$ & Gene & $\begin{array}{l}\text { AV/SA/ } \\
06\end{array}$ & $\begin{array}{l}\text { CK/Em/R66/ } \\
02\end{array}$ & $\begin{array}{l}\text { CK/Du/338/ } \\
01\end{array}$ & $\begin{array}{l}\text { CK/Du/383/ } \\
01\end{array}$ & $\begin{array}{l}\text { CK/Pak/UDL01/ } \\
08\end{array}$ & $\begin{array}{l}\text { qu/HK/G1/ } \\
97\end{array}$ & $\begin{array}{l}\text { qu/HK/Y280/ } \\
97\end{array}$ & $\begin{array}{l}\text { Ck/HK/G9/ } \\
97\end{array}$ \\
\hline & HA & 96.83 & 92.45 & 92.91 & 92.73 & 95.62 & 93.66 & 88.81 & 89.65 \\
\hline & NA & 92.00 & 97.00 & 97.26 & 97.01 & 94.00 & 95.00 & 93.53 & 92.53 \\
\hline \multirow{6}{*}{$\begin{array}{l}\mathrm{A} / \mathrm{CK} / \mathrm{TUN} / 12 / \\
10\end{array}$} & PB2 & 95.72 & 93.86 & 96.46 & 96.46 & 96.83 & 96.83 & 96.83 & 86.05 \\
\hline & NP & 98.2 & 97. 30 & 97.6 & 97.6 & 92 & 85.87 & 85.5 & 90.71 \\
\hline & M & 98.46 & 95.71 & 95.23 & 95.23 & 97.18 & 95.71 & 93 & 93.13 \\
\hline & NS & 97.77 & 96.53 & 96.16 & 96.61 & 94.00 & 90.72 & 96.83 & 90.6 \\
\hline & HA & 96.74 & 92.63 & 92.82 & 92.63 & 95.52 & 93.56 & 88.72 & 96.83 \\
\hline & NA & 92.00 & 97.26 & 97.26 & 97.26 & 94.00 & 95.27 & 93.78 & 96.83 \\
\hline \multirow{3}{*}{$\begin{array}{l}\mathrm{A} / \mathrm{MB} / \mathrm{TUN} / 51 / \\
10\end{array}$} & PB2 & 95.72 & 93.86 & 96.46 & 96.46 & 92.00 & 85.87 & 85.50 & 96.83 \\
\hline & NP & 97.90 & 97.70 & 97.90 & 97.90 & 94.91 & 97.30 & & 96.83 \\
\hline & M & 98.46 & 95.71 & 95.22 & 95.23 & 97.18 & 96.83 & 93.00 & 96.83 \\
\hline
\end{tabular}

The highest similarities are in bold face

Virus abbreviation are listed in Table. 2

a calculated based on the nucleotide sequences of HA, NA, PB2, NP, M and NS genes.

(nucleotides 1591 to 2130) that codes the region of PB2 protein located between positions 530 and 710 . Tree analysis of the PB2 gene showed that $\mathrm{Ck} / \mathrm{TUN} / 12 / 10$ and Migratory bird/TUN/51/10 isolates are related to the Middle Eastern isolates (more than 97\% similarity) and fall into a single group within the G1-like lineage (Figure 1c).

In the NP gene tree (Figure 1d), representative H9N2 viruses clustered into two distinct lineages, the G1-lineage including Middle Eastern, Qa/HK/G1/97, Asian strains, and Dk/HK/Y283/97 H5N1 like lineage. Besides, the H9N2 Tunisian isolates shared $97 \%$ to $98 \%$ similarity with other isolates such as A/Av/SA/91013406/06, A/ $\mathrm{Ck} / \mathrm{Em} / \mathrm{R} 666 / 02, \mathrm{~A} / \mathrm{Ck} / \mathrm{Du} / 338 / 01$ and showed a "sister group" relationship with $\mathrm{H} 6 \mathrm{~N} 1$ viruses of more than $97 \%$.

The matrix genes (Figure 1e) (regions of the overlapping reading frames of M1-M2, nucleotides 7 to 845) of $\mathrm{Ck} / \mathrm{TUN} / 12 / 10$ and $\mathrm{MB} / \mathrm{TUN} / 51 / 10$ strains showed a close relationship to those of Middle Eastern (95\% to 98\% similarity), and to other subtypes such as, Ck/ KHNC/100/04 H7N3 (96.93\%), Dk/HK/Y283/97 H5N1 (95.74\%), ph/HK/SSP44/02 H6N1 (95.23\%) strains.

The NS gene (nucleotides 1591 to 2130) of Ck/TUN/ $12 / 10$ showed evidence of reassortment with other viral subtypes. It was $95 \%$ and $92.9 \%$ similar to those of $\mathrm{A} /$ gs/11/99 (H6N1) and CK/HK/8761/01 (H5N1), respectively (Figure 1f).

\section{Molecular characteristics}

To analyze the receptor binding site, the connecting peptide and the Hemadsorption site of neuraminidase specificity of the Tunisian isolates, we have compared the HA amino acid sequences (deduced from the nucleotide sequences) with those of representative viruses from GenBank.

\section{Hemagglutinin}

The molecular determinants of pathogenecity and virulence of the HA protein are the HA1/HA2 connecting peptide sequence, specific amino acids (aa) residues at the receptor binding site (RBS), and the presence or absence of glycosylation sites around the receptor binding site.

HA cleavage site motif sequence of the Tunisian isolates was ${ }^{333}$ PARSSR* GLF $^{341}$ which is similar to other Asian H9N2 viruses including those from Hong Kong, Japan, Iran, Israel, Pakistan, and Saudi Arabia, Dubai. Residues at positions 110, 161, 163, 191, 198, 234, 235 and 236 are major components of the receptor binding site of the HA molecule. Tunisian viruses showed conservation of residues $\mathbf{P}^{110}, \mathrm{~W}^{161}, \mathrm{~T}^{\mathbf{1 6 3}}, \mathrm{H}^{191}, \mathrm{~A}^{198}$ and $\mathrm{I}^{\mathbf{2 3 5}}$ in the receptor binding pocket. The left (aa residues at position 234-239) and right (aa residues at position 148-152) edge of the binding pocket motif were: NGL/ QIGR and GTSKS, respectively.

The A/CK/TUN/12/10 H9N2 strain carried the amino acid substitution (Q234L), a mutation that correlates with a shift in affinity of the HA from avian type sialic receptors to human type and from a preference for a 2*3 link to a $2 * 6$ link between the sialic acid residues and galactose, whereas A/Migratory Bird/TUN/51/10 having Glu Q at this position. But, both strains had Gly (G) at position 228 at the RBS.

Analysis of HA protein sequences showed that Tunisian H9N2 isolates have many potential glycosylation 
sites with the N-X-T/S motif ( $\mathrm{X}$ can be any amino acid expect proline): 82-84 (NPS), 105-107 (NGT), 141-143 (NVT), 218-220 (NRT), 298-300 (NST), 305-307 (NIS) (Table 4).

\section{HB site of Neuraminidase}

Analysis of the neuraminidase active and framework sites of the NA protein revealed mutations in aa residues on 3 loops that interact directly with sialic acid; on loops carring amino acids 367-370-372, the three Ser (S) were substituted by KLA respectively, also D and Y substitution were found at residues 401, 406 respectively. Otherwise, the framework site contains $\mathrm{R}^{371}, \mathrm{~A}^{372}, \mathrm{~N}^{402}$, and $\mathrm{E}^{425}$ (Table 5).

\section{Molecular characteristics of internal proteins}

The current Tunisian strains displayed Glu (E) at position 627 of the PB2 protein; therefore, a change to Lys could serve as a marker of the virulence phenotype. In addition, two avian virus-like aa at positions 661 (A) and $702(\mathrm{~K})$, similar to $\mathrm{Ck} / \mathrm{HK} / 8733 / 01 \mathrm{H} 5 \mathrm{~N} 1$ strain isolated in 2001, were found (Table 5).

The nucleoprotein (NP) of Tunisian H9N2 strains retained conserved G1-lineage defining residues: R422, K430, T442, D455 and D480. However, Ser to Phe substitution at residue 402, found exclusively in Tunisian strains, similar to H5N1 strain circulated in 1997. Other aa specific for the nucleoprotein (NP) gene associated with host range, were not studied (Table 5).

Alignment of the M2 protein of current Tunisian H9N2 strains showed conserved G1 lineage defining Leu residue at position 10 . None of the Tunisian isolates contained substitutions at amino acid positions 26, 27, 30,31 or 34 , suggesting the absence of resistance to M2 blockers antiviral drugs such as amantadine. However, we have identified some substitutions at position 16 (Gly, G), 28 (Ile, I), related to the ion channel domain and associated with host range. In addition, Ile, Val and Pro substitutions were present in Tunisian H9N2 viruses at residue 15 (V15I), 46 (L46V) and 54 (S54P) of M1 protein, respectively. Avian virus like aa such as: $\mathrm{V}^{115}, \mathrm{~T}$ ${ }^{121}$ and $\mathrm{T}^{137}$ were also observed (Table 6).

Based on the analysis of the non structural protein gene (NS), our recent isolates did not show the five amino acid (80TIAS84) deletions, resulting in an NS1 protein of 230 amino acid in length and containing the "GSEV" PDZ ligand (PL) C-terminal motif, and did not harbor the mutation of Asp (D) to Glu (E) at position 92, required for high virulence. Besides, The RNA-binding domain exhibited amino acid residues P31, D34, R35, R38, K41, G45, R46 and T49. However, the effector domain carried the F103L, R184G and K217N

Table 4 Analysis of the amino acid sequences of the HA protein of Tunisian isolates with reference strains

\begin{tabular}{|c|c|c|c|c|c|c|c|c|c|c|c|c|c|c|}
\hline \multirow{3}{*}{ Virus } & \multicolumn{14}{|c|}{$\mathrm{HA}^{*}$} \\
\hline & \multicolumn{7}{|c|}{ Receptor binding Site (RBS) } & \multicolumn{2}{|c|}{$\begin{array}{l}\text { Left-edge of } \\
\text { binding pocket }\end{array}$} & \multicolumn{2}{|c|}{$\begin{array}{l}\text { Right-edge of } \\
\text { binding pocket }\end{array}$} & \multicolumn{2}{|c|}{$\begin{array}{l}\text { Connecting peptide } \\
\text { aa sequence }\end{array}$} & \multirow{2}{*}{$\begin{array}{c}\text { Glycosylation site } \\
\text { at position } \\
168\end{array}$} \\
\hline & 110 & 161 & 163 & 191 & 198 & 202 & 203 & 232 & 236 & 148 & 152 & 333 & 338 & \\
\hline $\mathrm{A} / \mathrm{Ck} / \mathrm{TUN} / 12 / 2010$ & $\mathrm{P}$ & W & $\mathrm{T}$ & $\mathrm{H}$ & A & L & Y & \multicolumn{2}{|c|}{ N G L I G } & \multicolumn{2}{|c|}{ G T S K S } & \multicolumn{2}{|c|}{$P A R S S R$} & + \\
\hline A/M B/TUN/51/2010 & $P$ & W & $\mathrm{T}$ & $\mathrm{H}$ & A & L & Y & \multicolumn{2}{|c|}{$N G \mathbf{Q} \mid G$} & \multicolumn{2}{|c|}{ G T S K S } & \multicolumn{2}{|c|}{ PARSSR } & + \\
\hline A/Av/SA/910136/06 & $P$ & W & $\mathrm{T}$ & $\mathrm{H}$ & $\mathbf{T}$ & L & Y & \multicolumn{2}{|c|}{$N G L \mid G$} & \multicolumn{2}{|c|}{ G T S K S } & \multicolumn{2}{|c|}{ PARSSR } & - \\
\hline A/Av/SA/910135/06 & $P$ & W & $\mathrm{T}$ & $\mathrm{H}$ & $A$ & L & Y & \multicolumn{2}{|c|}{$N G L \mid G$} & \multicolumn{2}{|c|}{ G T S K S } & \multicolumn{2}{|c|}{ PARSSR } & - \\
\hline $\mathrm{A} / \mathrm{Ck} / \mathrm{Du} / 338 / 01$ & $P$ & W & $\mathrm{T}$ & $\mathrm{H}$ & A & L & Y & \multicolumn{2}{|c|}{$N G L \mid G$} & \multicolumn{2}{|c|}{ G T S K S } & \multicolumn{2}{|c|}{ PARSSR } & - \\
\hline $\mathrm{A} / \mathrm{Ck} / \mathrm{Du} / 339 / 01$ & $P$ & W & $\mathrm{T}$ & $\mathrm{H}$ & A & L & Y & \multicolumn{2}{|c|}{$N G L M G$} & \multicolumn{2}{|c|}{ G T S K A } & \multicolumn{2}{|c|}{ PARSSR } & - \\
\hline $\mathrm{A} / \mathrm{Ck} / \mathrm{Du} / 383 / 02$ & P & W & $\mathrm{T}$ & $\mathrm{H}$ & A & L & Y & \multicolumn{2}{|c|}{$N G L \mathbf{M G}$} & \multicolumn{2}{|c|}{ G T S K A } & \multicolumn{2}{|c|}{ PARSSR } & - \\
\hline $\mathrm{A} / \mathrm{Ck} / \mathrm{Du} / 463 / 03$ & $\mathrm{P}$ & W & $\mathrm{T}$ & $\mathrm{H}$ & A & L & Y & \multicolumn{2}{|c|}{$N G L \mathbf{M} G$} & \multicolumn{2}{|c|}{ G T S K A } & \multicolumn{2}{|c|}{ PARSSR } & - \\
\hline $\mathrm{A} / \mathrm{Ck} / \mathrm{Em} / \mathrm{R} 66 / 02$ & $P$ & W & $\mathrm{T}$ & $\mathrm{H}$ & A & L & Y & NG & L G & G T & $\mathrm{KA}$ & & $S R$ & - \\
\hline $\mathrm{A} / \mathrm{Ck} / \mathrm{ls} / 386 / 07$ & $P$ & W & $\mathrm{T}$ & $\mathrm{H}$ & $E$ & L & Y & NG & $L G$ & G T & K S & & $S R$ & - \\
\hline $\mathrm{A} / \mathrm{Ck} / \mathrm{ls} / 292 / 08$ & $P$ & W & $\mathrm{T}$ & $\mathrm{H}$ & A & $\mathrm{L}$ & Y & $\mathrm{NG}$ & $I G$ & G T & K S & $P A$ & $S R$ & + \\
\hline $\mathrm{A} / \mathrm{Ck} / \mathrm{Pak} / \mathrm{UDL}-01 / 0$ & $P$ & W & $\mathrm{T}$ & $\mathrm{H}$ & A & L & Y & $\mathrm{NG}$ & IG & G T & K S & & $S R$ & + \\
\hline A/Ck/Pak/UDL-01/08 & P & W & $\mathrm{T}$ & $\mathrm{H}$ & A & L & Y & $\mathrm{NC}$ & I G & G T & K S & & $S R$ & - \\
\hline $\mathrm{A} / \mathrm{Qu} / \mathrm{HK} / \mathrm{G} 1 / 97$ & $\mathrm{P}$ & W & $\mathrm{T}$ & $\mathrm{H}$ & A & $\mathrm{L}$ & Y & $\mathrm{NG}$ & I G & G T & K S & $P A$ & $S R$ & - \\
\hline A/DK/HK/Y280/97 & $P$ & W & $\mathrm{T}$ & $\mathrm{H}$ & A & L & Y & $\mathrm{NG}$ & IG & G T & K S & $P A$ & $S R$ & - \\
\hline $\mathrm{A} / \mathrm{Ck} / \mathrm{HK} / \mathrm{G} 9 / 97$ & $P$ & W & $\mathrm{T}$ & $\mathrm{H}$ & $E$ & L & Y & ND & $\mathbf{Q}$ G & G I & R A & & $S R$ & - \\
\hline & P & W & $\mathrm{T}$ & $\mathbf{N}$ & $\mathbf{T}$ & L & Y & N G & $\mathbf{Q}$ G & $\mathrm{G} T$ & $\mathrm{KA}$ & & $S R$ & - \\
\hline & $P$ & W & $\mathrm{T}$ & $\mathbf{N}$ & $A$ & $\mathrm{~L}$ & Y & NG & $\mathbf{Q} G$ & G T & $\mathrm{K} \mathrm{A}$ & $P A$ & $S R$ & - \\
\hline
\end{tabular}

*numbering according to $\mathrm{H} 9,^{-/+}$absence or presence of the Glycosylation site. 
Table 5 Analysis of the amino acid sequences of the NA, PB2 and NP proteins of Tunisian isolates with reference strains

\begin{tabular}{|c|c|c|c|c|c|c|c|c|c|c|c|c|c|c|}
\hline \multirow[t]{3}{*}{ VIRUS } & \multicolumn{4}{|c|}{ NA } & \multicolumn{4}{|c|}{ PB2 } & \multicolumn{6}{|c|}{ NP } \\
\hline & \multicolumn{2}{|c|}{$\begin{array}{c}\text { Neuraminidase } \\
\text { active } \\
\text { site }(\mathrm{HB})\end{array}$} & \multicolumn{2}{|c|}{$\begin{array}{l}\text { Framework } \\
\text { site }\end{array}$} & \multirow[b]{2}{*}{547} & \multirow[b]{2}{*}{627} & \multirow[b]{2}{*}{661} & \multirow[b]{2}{*}{702} & \multirow[b]{2}{*}{402} & \multirow[b]{2}{*}{422} & \multirow[b]{2}{*}{430} & \multirow[b]{2}{*}{442} & \multirow[b]{2}{*}{455} & \multirow[b]{2}{*}{480} \\
\hline & 366. 373 & 399. 406 & 431. 433 & 425 & & & & & & & & & & \\
\hline $\mathrm{A} / \mathrm{Ck} / \mathrm{TUN} / 12 / 2010$ & IKKDLRAG & DSDNWSGY & PQE & $E$ & 1 & E & A & K & $\mathrm{F}$ & $\mathrm{R}$ & K & T & $\mathrm{D}$ & $\mathrm{D}$ \\
\hline A/MB/TUN/51/2010 & IKKDLRAG & DSDNWSGY & PQE & $E$ & 1 & E & A & K & $\mathrm{F}$ & R & K & T & D & $\mathrm{D}$ \\
\hline A/Av/SA/910136/06 & IKEESRAG & DSDNLSGY & PQE & E & 1 & E & A & K & S & $\mathrm{R}$ & K & T & D & $\mathrm{D}$ \\
\hline A/Av/SA/910135/06 & IKKDLRAG & DSDNWSGY & PQE & E & 1 & $E$ & A & K & S & $\mathrm{R}$ & K & $\mathrm{T}$ & D & D \\
\hline $\mathrm{A} / \mathrm{Ck} / \mathrm{Du} / 338 / 01$ & IKKDLRAG & DSDNWSGY & PQE & $E$ & V & E & A & K & S & $\mathrm{R}$ & K & T & D & D \\
\hline $\mathrm{A} / \mathrm{Ck} / \mathrm{Du} / 339 / 01$ & IKKDLRAG & DSDNWSGY & PQE & E & v & E & A & K & s & $\mathrm{R}$ & K & T & D & D \\
\hline $\mathrm{A} / \mathrm{Ck} / \mathrm{Du} / 383 / 02$ & IKKDLRAG & DSDNWSGY & $\mathrm{PQE}$ & $E$ & V & E & A & K & S & $\mathrm{R}$ & K & T & D & $\mathrm{D}$ \\
\hline $\mathrm{A} / \mathrm{Ck} / \mathrm{Du} / 463 / 03$ & IKKDLRAG & DSDNWSGY & PQE & E & V & $\mathrm{E}$ & A & K & S & $\mathrm{R}$ & K & T & D & D \\
\hline $\mathrm{A} / \mathrm{Ck} / \mathrm{Em} / \mathrm{R} 66 / 02$ & IKKDLRAG & DSDNWSGY & PQE & E & V & E & A & K & S & $\mathrm{R}$ & K & T & D & D \\
\hline $\mathrm{A} / \mathrm{Ck} / \mathrm{ls} / 386 / 07$ & IKKDSRAG & DSDNWSGY & PQE & E & V & E & A & K & S & $\mathrm{R}$ & K & T & D & D \\
\hline $\mathrm{A} / \mathrm{Ck} / \mathrm{ls} / 292 / 08$ & IKKDSRAG & DSDNWSGY & PQE & E & v & E & A & K & S & R & K & T & D & $\mathrm{D}$ \\
\hline A/Ck/Pak/UDL-01/05 & IKKDSRAG & DSDNWSGY & PQE & $E$ & V & E & v & K & S & R & K & T & D & $\mathrm{D}$ \\
\hline A/Ck/Pak/UDL-01/08 & IKKDSRAG & DSDNRSGY & PQE & $E$ & V & E & A & K & S & R & K & T & D & D \\
\hline A/Qu/HK/G1/97 & IKKDSRAG & DSDNWSGY & PQE & E & V & E & $\mathbf{T}$ & K & S & $\mathrm{R}$ & K & T & D & D \\
\hline A/DK/HK/Y280/97 & IKEDSRAG & DSDIRSGS & PQE & $E$ & V & E & v & K & S & R & K & T & D & D \\
\hline $\mathrm{A} / \mathrm{Ck} / \mathrm{HK} / \mathrm{G} 9 / 97$ & IKKDSRAG & DSDNWSGY & PKE & E & V & E & $\mathbf{T}$ & K & s & $\mathrm{R}$ & K & T & $\mathrm{D}$ & $\mathrm{D}$ \\
\hline A/Ck/HK/342/78(H5N1) & & & & & v & E & A & K & & & & & & \\
\hline $\mathrm{A} / \mathrm{Ck} / \mathrm{HK} / 485 / 97(\mathrm{H} 5 \mathrm{~N} 1)$ & & & & & V & E & A & K & & & & & & \\
\hline $\mathrm{A} / \mathrm{Ck} / \mathrm{Ch} / \mathrm{NARC} / 148 / 04(\mathrm{H} 7 \mathrm{~N} 3)$ & & & & & v & E & A & K & S & $\mathrm{R}$ & K & T & D & D \\
\hline $\mathrm{A} / \mathrm{Ck} / \mathrm{Pa} / 34668 / 95(\mathrm{H} 7 \mathrm{~N} 3)$ & & & & & V & E & A & K & & & & & & \\
\hline A/Ck/HK/156/97(H5N1) & & & & & & & & & $F$ & $\mathrm{R}$ & K & T & D & $\mathrm{D}$ \\
\hline A/Dk/HK/Y283/97(H5N1) & & & & & & & & & s & $\mathrm{R}$ & K & T & D & D \\
\hline A/Ck/HK/Y388/97(H5N1) & & & & & & & & & S & $\mathrm{R}$ & K & T & D & $\mathrm{D}$ \\
\hline A/Qu/HK/FB801/01(H6N1) & & & & & & & & & S & $\mathrm{R}$ & K & T & D & $\mathrm{D}$ \\
\hline $\mathrm{A} / \mathrm{Ck} / \mathrm{Pa} / 34668 / 95(\mathrm{H} 7 \mathrm{~N} 3)$ & & & & & & & & & $S$ & $\mathrm{R}$ & K & $\mathrm{T}$ & $\mathrm{D}$ & $\mathrm{D}$ \\
\hline
\end{tabular}

substitutions. Moreover, E227G mutation in C-terminal domain of the NS1 protein, introducing an S70I mutation into nuclear export protein (NEP), was also observed (Table 6).

\section{Discussion}

Infections of domestic poultry, especially chickens with H9N2 subtype of avian influenza virus (AIV) have been frequently reported in China, other Asian and North American countries, since the late 1990s. They have been grouped in different sublineages on the basis of antigenic and genetic properties. Although, H9N2 viruses do not satisfy the criteria for highly pathogenic avian influenza, they are unique among this category, infecting a wide variety of species, including chickens [21,22], quails [23], pigeons [24], turkeys [25], ducks [25-27], geese, pigs [28], and humans. Several studies have reported that G1- like H9N2 viruses can infect humans and can replicate in human alveolar epithelial cells and mouse respiratory system. Interestingly, they could emerge as human pathogens though reassortement in intermediate hosts, such as pigs and avian species, or through direct adaptation to human.

Since late 2009, H9N2 influenza A viruses have caused many outbreaks in Tunisian flocks. A second wave of AI was reported during July-October 2010. Here, we have provided the first comprehensive genetic data for the H9N2 subtype viruses circulating in Tunisian poultry flocks. Strains were collected from two different governorates situated in the northeastern part of Tunisia. Our findings revealed that H9N2 virus infection is well established in some Tunisian endemic areas. Therefore, understanding the genetic and the biological characteristics of H9N2 virus isolated from different species and regions can provide a comprehensive insight into the biology of H9N2, the ecology of AI virus, and the ability of migratory birds to disseminate influenza viruses. 
Table 6 Analysis of the amino acid sequences of the NS and M proteins of Tunisian isolates with reference strains

\begin{tabular}{|c|c|c|c|c|c|c|c|c|c|c|c|c|c|c|c|c|c|c|c|}
\hline \multirow[t]{3}{*}{ VIRUS } & \multicolumn{8}{|c|}{ NS1 } & \multirow{2}{*}{$\frac{\mathrm{NS2}}{\mathrm{NLS}^{\mathrm{b}}}$} & \multicolumn{3}{|c|}{ M1 } & \multicolumn{7}{|c|}{ M2 } \\
\hline & $\begin{array}{c}\text { Deletion } \\
\text { of aa }\end{array}$ & $\begin{array}{l}\text { Total } \\
\text { of no } \\
\text { of aa }\end{array}$ & PL motif & & & & & & & & & & & & & & & & \\
\hline & $80-84$ & & & 92 & 103 & 106 & 184 & 217 & 71 & 15 & 46 & 54 & 16 & 26 & 27 & 28 & 30 & 31 & 34 \\
\hline A/Ck/TUN/12/2010 & NO & 230 & GSEV & $D$ & $\mathrm{~L}$ & M & G & $\mathrm{N}$ & $\mathrm{S}$ & 1 & V & $P$ & G & $L$ & v & I & A & $S$ & G \\
\hline A/MB/TUN/51/2010 & - & - & - & - & - & - & - & - & - & 1 & v & $P$ & G & $L$ & V & I & A & S & G \\
\hline A/Av/SA/910136/06 & NO & 230 & GSEV & D & L & $M$ & G & $\mathrm{K}$ & $\mathrm{s}$ & । & L & $\mathrm{s}$ & D & L & V & v & A & $S$ & G \\
\hline A/Av/SA/910135/06 & NO & 230 & GSEV & D & $L$ & M & G & K & $\mathrm{S}$ & । & L & $\mathrm{S}$ & D & L & V & V & V & $S$ & G \\
\hline $\mathrm{A} / \mathrm{Ck} / \mathrm{Du} / 338 / 01$ & NO & 220 & GSEV & D & $F$ & M & G & K & $\mathrm{S}$ & । & L & $P$ & G & L & A & V & A & $S$ & G \\
\hline A/Ck/Du/339/01 & NO & 220 & GSEV & D & $\mathrm{F}$ & M & G & K & $\mathrm{S}$ & । & L & $P$ & G & L & A & V & A & $\mathrm{S}$ & G \\
\hline $\mathrm{A} / \mathrm{Ck} / \mathrm{Du} / 383 / 02$ & NO & 220 & GSEV & $\mathrm{D}$ & $\mathrm{F}$ & M & G & K & $\mathrm{S}$ & । & L & $P$ & G & L & A & V & A & S & G \\
\hline $\mathrm{A} / \mathrm{Ck} / \mathrm{Du} / 463 / 03$ & $\mathrm{NO}$ & 220 & GSEI & D & $\mathrm{F}$ & M & G & K & $\mathrm{S}$ & । & L & $P$ & G & L & V & V & A & $S$ & G \\
\hline A/Ck/Em/R66/02 & NO & 218 & GSEV & D & $\mathrm{F}$ & M & G & K & $\mathrm{S}$ & I & L & $P$ & G & L & V & V & A & $S$ & G \\
\hline $\mathrm{A} / \mathrm{Ck} / \mathrm{Is} / 386 / 07$ & NO & 230 & KSEV & D & $\mathrm{F}$ & M & G & K & $S$ & I & L & $\mathrm{S}$ & G & L & V & V & A & $S$ & G \\
\hline A/Ck/ls/292/08 & NO & 230 & GSEV & D & $\mathrm{F}$ & M & G & K & $\mathrm{S}$ & । & $\mathrm{L}$ & $\mathrm{S}$ & G & $L$ & V & V & A & $S$ & G \\
\hline A/Ck/Pak/UDL-01/05 & NO & 230 & GSEV & D & $\mathrm{F}$ & M & G & K & $\mathrm{s}$ & 1 & L & $P$ & G & $L$ & V & V & A & S & G \\
\hline A/Ck/Pak/UDL-01/08 & NO & 230 & KSEI & D & $\mathrm{F}$ & M & G & K & $\mathrm{s}$ & । & L & $P$ & G & L & V & V & A & $S$ & G \\
\hline A/Qu/HK/G1/97 & NO & 230 & EPEV & $\mathrm{E}$ & L & I & G & $N$ & $\mathrm{~S}$ & । & L & $P$ & G & L & V & V & A & $S$ & G \\
\hline A/DK/HK/Y280/97 & NO & 230 & EPEV & D & $L$ & । & G & K & $S$ & I & $L$ & $P$ & G & $L$ & V & V & A & $S$ & G \\
\hline A/Ck/HK/G9/97 & NO & 218 & EPEV & D & $L$ & । & G & K & $\mathrm{s}$ & । & $\mathrm{L}$ & $P$ & G & $L$ & V & V & A & $S$ & G \\
\hline $\mathrm{A} / \mathrm{Par} / \mathrm{Ch} / 1 / 97$ & NO & 230 & EPEV & $\mathrm{E}$ & L & । & G & $N$ & $\mathrm{~S}$ & । & L & $P$ & G & $\mathrm{L}$ & V & V & A & S & G \\
\hline A/DK/HK/Y388/97(H5N1) & NO & 218 & EPEV & $\mathrm{E}$ & $L$ & । & G & $N$ & $\mathrm{~s}$ & । & L & $P$ & G & $\mathrm{L}$ & V & V & A & S & G \\
\hline A/DK/HK/8761/01(H5N1) & YES & 230 & ESEV & D & $\mathrm{F}$ & M & G & $N$ & $\mathrm{~s}$ & । & L & $P$ & G & L & V & V & A & S & G \\
\hline A/Ck/Ng/1904/92(H7N1) & NO & 230 & ESEV & D & $\mathrm{F}$ & M & G & $N$ & $\mathrm{~S}$ & I & L & $P$ & G & $L$ & V & V & A & $\mathrm{S}$ & G \\
\hline A/gs/NL1/99(H6N1) & NO & 230 & ESEV & D & $\mathrm{F}$ & M & G & $N$ & $\mathrm{~S}$ & I & L & $P$ & G & L & V & V & A & $\mathrm{S}$ & G \\
\hline $\mathrm{A} / \mathrm{Ck} / \mathrm{Sh} / 1197 / 01(\mathrm{H} 6 \mathrm{~N} 1)$ & NO & 230 & ESEV & $\mathrm{D}$ & $\mathrm{F}$ & M & G & $\mathrm{N}$ & $\mathrm{s}$ & । & $L$ & $P$ & $\mathrm{G}$ & $\mathrm{L}$ & V & V & $A$ & $S$ & $G$ \\
\hline
\end{tabular}

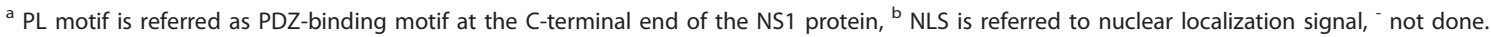

The Blast analysis (NCBI) of the nucleotide sequences of $\mathrm{HA}$ and NA genes showed that $\mathrm{A} / \mathrm{Ck} / \mathrm{TUN} / 12 / 10$ and A/Migratory Bird/TUN/51/10 were the most closely related to the Middle Eastern isolates belonging to the G1- like lineage in the H9N2 subtype (more than 96.5\% similarity).

The results of the phylogenetic analyses were basically in agreement with the blast data, and confirmed that our isolates fall, together with the Middle Eastern strains, into a distinct cluster, related to the G1 lineage; a finding that may indicate a common origin.

The internal PB2, NP, M, NS genes were also similar to those of other Middle Eastern strains, which can be traced back to the same G1- like lineage. In addition, NP and NS genes seemed to have undergone broad reassortments with $\mathrm{H} 5 \mathrm{~N} 1, \mathrm{H} 7 \mathrm{~N} 3, \mathrm{H} 7 \mathrm{~N} 1, \mathrm{H} 6 \mathrm{~N} 1$ influenza virus subtypes as described for previous isolated strains $[18,29,30]$. This diversity reflects an increased spread of such viruses through avian species' migration. It is difficult to explain whether and how these reassortments have occurred because of the lack of local and regional epidemiological information.
Based on the deduced amino acid sequences, the HA1-HA2 connecting peptides of the Tunisian avian H9N2 isolates did not harbor multiple basic amino acids: PARSSR/GL as found for recently isolated H9 viruses in Middle East [31] and Asia [32,33]. This might indicate the LPAI nature of H9N2 strains, although the motif for these viruses is similar to the RX-RYK-R required for the highly pathogenic $\mathrm{H} 5$ and $\mathrm{H} 7$ subtypes $[34,35]$. These genetic findings suggested that our H9N2 viruses may have the potential to acquire basic amino acids in the HA connecting peptide sequence needed to become highly pathogenic through the addition of single basic amino acid at the -4 position.

Moreover, A/Migratory bird/TUN/51/10 possessed a Glu (Q) at position 234 in the HA1 portion (H9 numbering; 226 in $\mathrm{H} 3$ numbering), whereas A/Ck/TUN/12/ 10 showed a leu $(\mathrm{L})$, a receptor binding site residue, typical for human influenza virus displaying human virus-like cell tropism through an association with a preferential binding of sialic acid (SA) to galactose in $\alpha 2,6$ linkage $[9,36]$. A leu (L) residue at position 234 in the HA receptor binding site (RBS) was found to be 
important for the transmission of the H9N2 viruses in ferrets [37]. In previous study, Wan suggested that Q234L substitution, found in G1, Y280 and G9 lineages, isolated in Hong Kong, allows H9N2 viruses to preferentially infect non ciliated cells and grow more efficiently in human airway epithelial cell cultures; thus, increasing the infection severity in humans [12]. Our findings suggested that $\mathrm{A} / \mathrm{Ck} / \mathrm{TUN} / 12 / 10$ may have segregated from the migratory A/Migratory bird/TUN/51/ 10 strain acquiring an affinity for the human receptor binding profile. These findings may be attributed to a particular introduction of a new virus that has been circulating within poultry species.

Remarkably, residue at position 198 within the receptor binding pocket has been reported to influence the affinity of virus binding to SA receptor; high affinity to the human like receptor being with $\mathrm{V}$ at position 198, intermediate with $\mathrm{T}$ and low with $\mathrm{A}$ [38]. It can be predicted that the Tunisian $\mathrm{A} / \mathrm{Ck} / \mathrm{TUN} / 12 / 10$ isolate has a weaker affinity binding to human like receptor, but this finding need to be further confirmed by experimental studies.

Analysis of potential glycosylation site motif N-X-S/T in the HA1 protein of Tunisian H9N2 isolates, revealed some sites at positions 82, 105, 141, 298, 305. Additional glycosylation site at position 168 was observed compared with representative reference strains. It has been suggested that the alteration in the glycosylation pattern influences the adaptation of avian influenza viruses to poultry by altering their pathogenecity and antigenicity and helps to the evasion from the host antibody response [39-41].

The NA of the new Tunisian isolates carried substitutions in the HB site, similar to those of other avian H9N2 viruses isolated in Asia and Middle Eastern during human pandemic $\mathrm{H} 2 \mathrm{~N} 2$ and $\mathrm{H} 3 \mathrm{~N} 2$ that bind to $\alpha$ -2, 6 -linked receptors [42]. These viruses were showed to be under a positive selection pressure, resulting in compatible combinations of HA and NA [38].

Based on the deduced amino acid sequence, the Tunisian H9N2 isolates displayed Glu (E) at position 627 of the PB2 protein. Likewise, a single aa substitution in PB2 protein (E627K) can dramatically alter the virulence and enhance viral replication in mice [43] and other mammals [44-46]. Two avian virus-like aa at positions 661 (A) and $702(\mathrm{~K})$, as seen in H5N1 strains, were identified in the $\mathrm{PB} 2$ protein. These specific aa are located in the functional domain responsible for interaction with other polymerase components [47].

The main function of the NP is encapsidation of the viral genome to form a ribonucleoprotein particle for transcription and packaging; it interacts with other viral PB1, PB2, M1 and cellular proteins (Importin $\alpha, \mathrm{F}$-actin, CRM1/exportin 1) for viral transcription and nuclear transportation controls [48]. The NP aa sequence of the Tunisian isolates retained conserved G1-lineage defining residues. Interestingly, a new mutation (S402F), which has not been seen before, was detected in the NP protein. This mutation was previously found in the H5N1 subtype instead of Ser in all other H9N2 subtypes compared in this study (Table 5).

It has been reported that aa residues at positions 15 , $115,121,137,240$ in virus matrix protein are linked with increased replication in mammals or increased pathogenecity in small animal models [49,50]; an Ile substitution was present in Tunisian H9N2 viruses at aa position 15 (V15I). No one contained substitutions at aa positions $26,27,30,31$ or 34 within the transmembrane domain of M2 protein, maintaining a genotype associated with sensitivity to adamantadine M2 blocker antiviral drugs [51]. It has been known that amantadine binds to the ion channel region of the M2 protein and prevents the release of viral RNA into cells [52]. Tunisian H9N2 strains harbor two human virus- like amino acids at positions 16 (Gly, G) and 28 (Ile, I) which are related to the ion channel domain and associated with host range $(49,50)$, but the role of these substitutions on increased replication efficiency in mammalian cells is not yet known.

A Val substitution at position 46 was also detected for the first time in our strains; however, all other H9N2 and other IA subtypes have leu at this position (Table 6). Interestingly, this substitution should be considered.

Recent studies have suggested that NS1 protein suppresses the host antiviral defenses at multiples levels and correlation between NS1 and virulence has been reported [53-55]. Molecular analysis showed that our isolates contained an NS1 protein, with 230 aa in lengh, typical of H9N2 viruses. A recent study has shown that increasing the length of the 2009 H1N1 NS1 protein to 230 aa does not increase virus replication in human and pig cells [56]. Other study showed that viruses containing NS1 truncations were found to induce more interferon than viruses with full- length NS1 proteins and were correspondingly more attenuated in mice [57].

In the RNA- binding domain of NS1, A/Ck/TUN/12/ 2010 isolate contained R38 and K41, which are shown to be critical for RNA binding. as well amino acid residues P31, D34, R35, G45, R46, T49 and D55, which also mediate NS1-dsRNA interaction. Residue 55 is located within the third alpha- helix (residues 54-70) of the dsRNA-binding domain (RBD (residues 1-73) of NS1 [58]. It is documented that variation of NS1-55 from Asp (D) to gly (G) represents loss of changed aa which may stabilize the coiled- coiled helical structure. In addition, our strains exhibited no differences in the second nuclear localization sequences (NLS2) motif, or change in the amino acid D at position 92. Some studies 
reported a mutation of asp (D) to Glu (E) to be related to virulence of H5N1 in mammalian species and cytokine resistance [59]. Nevertheless, their effector domain carried Leu at position 103 and Gly at residue 184. In fact, F103L and M106I mutations are adaptive genetic determinants of growth and virulence in both human and avian NS1 genes in the mouse model [60]. Likewise, it has been demonstrated that, in addition to its contribution to cleavage and polyadenylation specificity factor (CPSF) binding, Gly 184 strongly influence viral virulence by an unknown mechanism which does not involve the INF system [61].

An Asp (N) was found at residue 217 only in Ck/ TUN/12/2010 strain that differs from the other H9N2 strains which have $\mathrm{K}$ at this position, but similar to those of H5N1 strain CK/HK/8761/01 (Table 4). However, the biological significance of this substitution is not yet known.

Also, Ck/TUN/12/2010 didn't exhibit a five amino (80TIAS84) deletion observed in 2001 in poultry in Hong Kong and has, since, became the most common sequence found in the HP viruses. Long et al, demonstrated that viruses containing NS1 with 5 amino acid deletion (80TIAS84) residues showed increased virulence in both mouse and poultry [62] but the biological significance of these deletions is not fully understood yet.

Fortunately, previous study, performed on large scale sequence analysis of viruses isolated from different birds and mammalian species, have identified that the $\mathrm{C}$-terminal domain of NS1 functions as a species-specific virulence domain: the vast majority of avian influenza viruses have an NS1 protein with a PDZ ligand (PL) C-terminal ESEV domain, while typical human viruses have a conserved RSKV domain. NS1 proteins with C-terminal ESEV, KSEV, and EPEV domains were shown to bind to PDZ domains containing cellular proteins $[63,64]$. Soubies et al demonstrated that RSKV motif, which lacks a PDZ- binding domain, replicated to higher titers than ESEV in humans and ducks cells, suggesting the ability of NS1 to interact with PDZ containing proteins does not contribute to virulence in the host species [65]. Nevertheless, it has been showed that insertion of four C-terminal aa, either ESEV, KSEV, or EPEV, into avirulent viruses resulted in an increase in virus virulence and caused severe disease in mice [52]. The H9N2 viruses recently isolated in Tunisia, have a PL motif "GSEV" previously found in Dubai strains during 2001-2003 (data not published); but the biological signification of this motif is unknown. Interestingly, the E227G mutation in NS1 introduces an S70I mutation into nuclear export protein.

\section{Conclusion}

In the present study, we characterized two Tunisian H9N2 strains isolated from disease outbreaks in commercial chicken and migratory bird from different geographic areas. Our findings indicate that CK/TUN/ $12 / 10$ isolate has evolved and reassorted with other influenza viruses and has acquired an affinity for the human receptor binding profile. Otherwise, the biological significance of new detected substitutions founded in some internal genes and the PDZ ligand polymorphism of the NS protein should be tested.

Actually and face to the high mortality, we are preparing for an active program to develop and evaluate vaccines against H9N2 to control the further spread of the disease in the industrial poultry production sectors. Interestingly, continuous monitoring of viral genetic changes throughout the years is warranted to monitor variations of Influenza viruses in the field.

\section{List of abbreviations}

aa: amino acid; AIV: Avian Influenza virus; HA: hemagglutinin; HB: heamadsorption; HPAIV: highly pathogenic type; LPAl: Low pathogenic type; M: matrix; NA: neuraminidase; NP: nucleoprotein; NS: non structural; PB2: polymerase; PL: PDZ ligand; RBS: receptor binding site

\section{Acknowledgements}

This study was supported by the Research Grant from the Tunisian Ministry of Research and was a part of research program of the laboratory of Veterinary Microbiology (Grant reference MEV09).

\section{Author details}

${ }^{1}$ Veterinary Microbiology laboratory, Pasteur Institute of Tunis, 1002 TunisBelvédère, Tunisia. ${ }^{2}$ INRA, UMR 1225, Ecole nationale vétérinaire de Toulouse, F-31076 Toulouse, France.

\section{Authors' contributions}

WT is a PhD, who carried out the H9N2 avian influenza virus genes detection by RT-PCR and was involved in the sequencing assays, phylogenetic and amino acid analysis, coordinated the work described, and drafted of the manuscript. JN and IL were involved in its design and coordination. JLG involved in drafting the manuscript or revising it critically for important intellectual content. AG conceptualized the study, supervised all facets of the research, and involved in design of the trials, assisting in the writing process. All authors read and approved the final manuscript.

\section{Competing interests}

The authors declare that they have no competing interests.

Received: 23 August 2011 Accepted: 12 October 2011

Published: 12 October 2011

\section{References}

1. Lamb RA, Krug RM: Orthomyxoviridae: the viruses and their replication. In Fields Vrology. Edited by: Knipe DM, Howley PM, Chanock RM, Melnick JL, Momath TP, Roizman S. Philadelphia Lippincott Williams 2001:1487-1532.

2. Chang-Won L, Yehia MS: Avian Influenza virus. Comp Immun Microbiol Infec Dis 2009, 32(4):301-310.

3. Butt KM, Smith GJ, Chen H, Zhang L, Leung YH, Xu KM, Lim W, Webster RG, Yuen KY, et al: Human infection with an avian H9N2 influenza A virus in Hong Kong in 2003. J Clin Microbiol 2005, 43:5760-5767.

4. Choi YK, Ozaki H, Webby RJ, Webster RG, Peiris JS, Poon LL, Butt C, Leung YHC, Guan Y: Continuing evolution of H9N2 influenza viruses in Southeastern China. J Virol 2004, 78:8609-8614.

5. Peiris M, Yuen KY, Leung KH, Chan PL, Lai SIp, RW M, Orr K, Shortridge KF: Human infection with influenza H9N2. Lancet 1999, 354:916-917.

6. Peiris S, Guan Y, Markwell D, Ghose P, Webster RG, Shortridge KF: Cocirculation of avian H9N2 and contemporary "human" H3N2 influenza 
A viruses in pigs in southeastern China: potential for genetic reassortment? J Virol 2001, 75:9679-9686.

7. Guo YJ, Li JW, Cheng I: Discovery of humans infected by avian influenza A (H9N2) virus. Chin J Exp Clin Virol 1999, 15:105-108.

8. Guan Y, Shortridge KF, Krauss S, Chin PS, Dyrting KC, Ellis TM, Webster RG, Peiris M: H9N2 influenza viruses possessing H5N1-like internal genomes continue to circulate in poultry in southeastern China. J virol 2000, 74:9372-9380.

9. HaghighatJahromi M, Asasi K, Nili H, Dadras H, Shooshtari AH: Coinfection of avian influenza virus (H9N2 subtype) with infectious bronchitis live vaccine. Arch Virol 2008, 153:651-655.

10. Kishida N, Sakoda Y, Eto M, Kida H: Co-infection of Staphylococcus aureus or Haemophilus paragallinarum exacerbates H9N2 influenza A virus infection in chickens. Arch Virol 2004, 149:2095-2104.

11. Guan Y, Shortridge KF, Krauss S, Webster RG: Molecular characterization of H9N2 influenza viruses: were they the donors of the "internal" genes of H5N1 viruses in Hong Kong? Proc Natl Acad Sci USA 1999, 96:9363-9367.

12. Wan H, Perez DR: Amino acid 226 in the hemagglutinin of H9N2 influenza viruses determines cell tropism and replication in human airway epithelial cells. J Virol 2007, 81:5181-5191.

13. OIE: Manual of diagnostic tests and vaccines for terrestrial animals. Highly Pathogenic Avian Influenza OIE, Paris, France; (Chapter 2.1.14), Updated on 08.07.2005.

14. OIE: Update on highly pathogenic avian Influenza in animals (Type H5 and H7).[http://www.oie.int/animal-health-in-the-world/update-on-avianinfluenza/2011].

15. Xie Z, Pang YS, Liu J, Deng X, Tang X, Sun J, Khan MI: A multiplex RT-PCR for detection of type $A$ influenza virus and differentiation of avian $\mathrm{H} 5$, H7, and H9 hemagglutinin subtypes. Mol Cell Probes 2006, 20:245-249.

16. Cooper $L A$, Subbarao $K: A$ simple restriction fragment length polymorphism-based strategy that can distinguish the internal genes of human H1N1, H3N2, and H5N1 influenza A viruses. J Clin Microbiol 2000, 38(supp 7):2579-2583.

17. WHO: Recommended Laboratory Tests to Identify Avian Influenza A Virus in Specimens from Humans. 2005 [http://www.who.int/csr/resources/ publications/influenza/WHO_CDS_EPR_GIP_2006_4r1.pdf].

18. Kwon HJ, Cho SH, Kim MC, Ahn YJ, Kim SJ: Molecular epizootiology of recurrent low pathogenic avian influenza by H9N2 subtype virus in Korea. Avian Pathol 2006, 35(4):309-315

19. Lee MS, Chang PC, Shien JH, Cheng MC, Shieh HK: Identification and subtyping of avian influenza viruses by reverse transcription-PCR. J Virol Methods 2001, 97(supp1-2):13-22.

20. Chi-Ho C, Keh-Liang L, You C, Ya-Li W, Yu-Tsai C, Hsiao-Li T, Happy-K S, WuTse L: Amplification of the entire genome of influenza A virus H1N1 and H3N2 subtypes by reverse-transcription polymerase chain reaction. $J$ Virol Method 2006, 136(supp1-2):38-40.

21. Wu R, Sui ZW, Zhang HB, Chen QJ, Liang WW, Yang KL, Xiong Z, Liu ZW, Chen Z, Xu DP: Characterization of a pathogenic H9N2 influenza A virus isolated from central China in 2007. Arch Virol 2008, 153:1549-1555.

22. Roussan DA, Khawaldeh GY, Al Rifai RH, Totanji WS, Shaheen IA: Avian influenza virus H9 subtype in poultry flocks in Jordan. Prev Vet Med 2009, 88:77-81.

23. Xu KM, Li KS, Smith GJ, Li JW, Tai H, Zhang JX, Webster RG, Peiris JS, Chen H, Guan Y: Evolution and molecular epidemiology of H9N2 influenza A viruses from quail in southern China, 2000 to 2005. J Virol 2007, 81:2635-2645.

24. Nagarajan S, Rajukumar K, Tosh C, Ramaswamy V, Purohit K, Saxena G, Behera P, Pattnaik B, Pradhan HK, Dubey SC: Isolation and pathotyping of H9N2 avian influenza viruses in Indian poultry. Vet Microbiol 2009, 133:154-63.

25. Perk S, Golender N, Banet-Noach C, Shihmanter E, Pokamunsky S, Pirak M, Tendler Y, Lipkind M, Panshin A: A Phylogenetic analysis of hemagglutinin, neuraminidase, and nucleoprotein genes of H9N2 avian influenza viruses isolated in Israel during the 2000-2005 epizootic. Comp Immunol Microbiol Infect Dis 2009, 32:221-238.

26. Kwon HJ, Cho SH, Kim MC, Ahn YJLL, Yu KZ, Yuen KY, Shortridge KF, Webster RG, Guan Y: Characterization of $\mathrm{H} 9$ subtype influenza viruses from the ducks of southern China: a candidate for the next influenza pandemic in humans? J Virol 2003, 77:6988-6994.

27. Hossain MJ, Hickman D, Perez DR: Evidence of expanded host range and mammalian-associated genetic changes in a duck H9N2 influenza virus following adaptation in quail and chickens. PLOS ONE 2008, 3: e3170.

28. Yu H, Hua RH, Wei TC, Zhou YJ, Tian ZJ, Li GX, Liu TQ, Tong GZ: Isolation and genetic characterization of avian origin H9N2 influenza viruses from pigs in China. Vet Microbiol 2008, 131:82-92.

29. Iqbal M, Yaqub T, Reddy K, McCauley JW: Novel genotypes of H9N2 influenza A viruses isolated from poultry in Pakistan containing NS genes similar to highly pathogenic H7N3 and H5N1 viruses. PLOS ONE 2009, 4:e5788.

30. Zhang P, Tang Y, Liu X, Liu W, Zhang X, Liu H, Peng D, Gao S, Wu Y, Zhang L, Lu S: A novel genotype H9N2 influenza virus possessing human H5N1 internal genomes has been circulating in poultry in eastern China since 1998. J Virol 2009, 83:8428-8438.

31. Aamir B, Wernery U, Ilyushina N, Webster RG: Characterization of avian H9N2 influenza viruses from United Arab Emirates 2000-2003. Virology 2007, 361:45-55.

32. Ge FF, Zhou JP, Liu J, Wang J, Zhang WY, Sheng LP, Xu F, Ju HB, Sun QY, Liu PH: Genetic Evolution of H9 Subtype Influenza Viruses from Live Poultry Markets in Shanghai, China. J Clin Microbiol 2009, 47:3294-3300.

33. Homayounimehr AR, Dadras H, Shoushtari A, Pourbakhsh SA: Sequence and phylogenetic analysis of the haemagglutinin genes of H9N2 avian influenza viruses isolated from commercial chickens in Iran. Trop Anim Health Prod 2010, 42:1291-1297.

34. Perdue ML, García M, Senne Fraire M: Virulence-associated sequence duplication at the hemagglutinin cleavage site of avian influenza viruses. Virus Res 1997, 49:173-186.

35. Kawaoka Y, Webster RG: Sequence requirements for cleavage activation of influenza-virus hemagglutinin expressed in mammalian-cells. Proc Natl Acad Sci USA 1998, 85:324-328.

36. Kawaoka Y, Webster RG, Paulson JC: Receptor specificity in human, avian, and equine $\mathrm{H} 2$ and $\mathrm{H} 3$ influenza virus isolates. Virology 1994, 205:17-23.

37. Wan H, Sorrell EM, Song H, Hossain MJ, Ramirez-Nieto G, Monne I, Stevens J, Cattoli G, Capua I, Li-Mei Chen , Ruben OD, Julia B, James CP, Christy B, Richard W, Jorge B, Mohammad QAN, Daniel RP: Replication and transmission of H9N2 influenza viruses in ferrets: evaluation of pandemic potential. PLOS ONE 2008, 3:e2923.

38. Matrosovich MN, Krauss S, Webster RG: H9N2 influenza A viruses from poultry in Asia have human virus-like receptor specificity. Virology 2001, 281:156-162.

39. Ohuchi M, Orlich M, Ohuchi R, Simpson BE, Garten W, Klenk HD, Rott R: Mutations at the cleavage site of the hemagglutinin after the pathogenicity of influenza virus A/chick/Penn/83 (H5N2). Virology 1989, 168:274-280.

40. Matsuoka Y, Swayne DE, Thomas C, Rameix-Welti MA, Naffakh N, Warnes C, Altholtz M, Donis R, Subbarao K: Neuraminidase stalk length and additional glycosylation of the hemagglutinin influence the virulence of influenza H5N1 viruses for mice. J Virol 2009, 83:470-480.

41. Ji K, Jiang WM, Liu S, Chen JM, Chen J, Hou GY, Li JP, Huang BX: Characterization of the hemagglutinin gene of subtype $\mathrm{H} 9$ avian influenza viruses isolated in 2007-2009 in China. J Virol Methods 2010, 163:186-189.

42. Gambarian AS, lamnikova SS, L'vov DK, Robertson JS, Webster RG, Matrosovich MN: Differences in receptor specificity between the influenza A viruses isolated from the duck, chicken, and human. Mol Biol (Mosk) 2002, 36:542-549.

43. Wu R, Zhang H, Yang K, Liang W, Xiong Z, Liu Z, Yang X, Shao H, Zheng X, Chen $M, X u$ D: Multiple amino acid substitutions are involved in the adaptation of H9N2 avian influenza virus to mice. Vet Microbiol 2009, 138:85-91.

44. Hatta M, Gao P, Halfmann P, Kawaoka Y: Molecular basis for high virulence of Hong Kong H5N1 influenza A viruses. Science 2001, 293:1840-1842

45. Manzoor R, Sakoda Y, Nomura N, Tsuda Y, Ozaki H, Okamatsu M, Kida H: PB2 protein of a highly pathogenic avian influenza virus strain A/ chicken/Yamaguchi/7/2004 (H5N1) determines its replication potential in pigs. J Virol 2009, 83:1572-1580.

46. Steel J, Lowen AC, Mubareka S, Palese P: Transmission of influenza virus in a mammalian host is increased by PB2 amino acids $627 \mathrm{~K}$ or $627 \mathrm{E} / 701 \mathrm{~N}$. PLoS Pathog 2009, 5:e1000252.

47. Perales B, de la Luna S, Palacios I, Ortín J: Mutational analysis identifies functional domains in the influenza A virus PB2 polymerase subunit. J Virol 1996, 70:1678-1686. 
48. Portela A, Digard P: The influenza virus nucleoprotein: a multifunctional RNA-binding protein pivotal to virus replication. J Gen Virol 2002, 83:723-734.

49. Shaw M, Cooper L, Xu X, Thompson W, Krauss S, Guan Y, Zhou N, Klimov A, Cox N, Webster R, Lim W, Shortridge K, Subbarao K: Molecular changes associated with the transmission of avian influenza a H5N1 and H9N2 viruses to humans. J Med Virol 2002, 66:107-114.

50. Chen GW, Chang SC, Mok CK, Lo YL, Kung YN, Huang JH, Shih YH, Wang JY, Chen CJ, Shih SR: Genomic signatures of human versus avian influenza A viruses. Emerg Infect Dis 2006, 12:1353-1360.

51. Suzuki H, Saito R, Masuda H, Oshitani H, Sato M, Sato I: Emergence of amantadine-resistant influenza A viruses: epidemiological study. J Infect Chemother 2003, 9:195-200.

52. Pinto LH, Holsinger LJ, Lamb RA: Influenza virus $M 2$ protein has ion channel activity. Cell 1992, 69:517-528.

53. Jackson D, Hossain MJ, Hickman D, Perez DR, Lamb RA: A new influenza virus virulence determinant: the NS1 protein four C-terminal residues modulate pathogenicity. Proc Natl Acad Sci USA 2008, 105:4381-4386.

54. Jiao P, Tian G, Li Y, Deng G, Jiang Y, Liu C, Liu W, Bu Z, Kawaokam Y, Chen $\mathrm{H}$ : A single-amino-acid substitution in the NS1 protein changes the pathogenicity of H5N1 avian influenza viruses in mice. J Virol 2008, 82:1146-1154.

55. Noah DL, Twu KY, Krug RM: Cellular antiviral responses against influenza A virus are countered at the posttranscriptional level by the viral NS1A protein via its binding to a cellular protein required for the $3^{\prime}$ end processing of cellular pre-mRNAS. Virology 2003, 307:386-395.

56. Hale BG, Steel J, Manicassamy B, Medina RA, Ye J, Hickman D, Lowen AC Perez DR, García-Sastre A: Mutations in the NS1 C-terminal tail do not enhance replication or virulence of the 2009 pandemic H1N1 influenza A virus. J Gen Virol 2010, 91:737-742.

57. Hale BG, Randall RE, Ortín J, Jackson D: The multifunctional NS1 protein of influenza A viruses. J Gen Virol 2008, 89:2359-2376.

58. Weirong W, Kelly R, Patricia L, ChenY C, Gaetano TM, Robert MK: RNA binding by the novel helical domain of the influenza virus NS1 protein requires its dimer structure and a small number of specific basic amino acids. RNA 1999, 5:195-205.

59. Seo SH, Hoffmann E, Webster RG: The NS1 gene of H5N1 influenza viruses circumvents the host anti-viral cytokine responses. Virus Res 2004, 103:107-113

60. Dankar SK, Wang S, Ping J, Forbes NE, Keleta L, Li Y, Brown EG: Influenza A virus NS1 gene mutations F103L and M106I increase replication and virulence. Virol J 2011, 8:13

61. Steidle S, Martínez-Sobrido L, Mordstein M, Lienenklaus S, García-Sastre A, Stäheli P, Kochs G: Glycine 184 in nonstructural protein NS1 determines the virulence of influenza A virus strain PR8 without affecting the host interferon response. J Virol 2010, 84:12761-1270.

62. Long JX, Peng DX, Liu YL, Wu YT, Liu XF: Virulence of H5N1 avian influenza virus enhanced by a 15 -nucleotide deletion in the viral nonstructural gene. Virus Genes 2008, 36:471-480.

63. Obenauer JC, Denson JP, Mehta K, Su X, Mukatira S, Finkelstein DB, Xu X, Wang J, Ma J, Fan Y, Rakestraw KM, Webster RG, Hoffmann E, Krauss $S$, Zheng J, Zhang Z, Naeve CW: Large-scale sequence analysis of avian influenza isolates. Science 2006, 311:1576-1580.

64. Tonikian R, Zhang Y, Sazinsky SL, Currell BJ, Yeh H, Reva B, Held HA Appleton BA, Evangelista M, Wu Y, Xin X, Chan AC, Seshagiri S, Lasky LA, Sander C, Boone C, Bader GD, Sidhu SS: A specificity map for the PDZ domain family. PLOS Biol 2008, 6:e239.

65. Soubies SM, Volmer C, Croville G, Loupias J, Peralta B, Costes P, Lacroux C, Guérin JL, Volmer R: Species-specific contribution of the four C-terminal amino acids of influenza A virus NS1 protein to virulence. J Virol 2010, 84(supp13):6733-6747.

\section{doi:10.1186/1743-422X-8-467}

Cite this article as: Tombari et al: Genetic evolution of low pathogenecity H9N2 Avian influenza viruses in Tunisia: acquisition of new mutations. Virology Journal 2011 8:467.

\section{Submit your next manuscript to BioMed Central and take full advantage of:}

- Convenient online submission

- Thorough peer review

- No space constraints or color figure charges

- Immediate publication on acceptance

- Inclusion in PubMed, CAS, Scopus and Google Scholar

- Research which is freely available for redistribution

Submit your manuscript at www.biomedcentral.com/submit
C Biomed Central 